УДК

349.444(4)"1918/1928"

351.54(4)"1918/1928"

Оригиналан научни рад

Примљен: 5. 12.2016.

Прихваћен: 16. 1. 2017.

Aleksandar R. MILETIĆ

Institut for Recent History of Serbia

armiletic@gmail.com

\title{
Housing Disputes and Politics; \\ Socio-Political Context of the Tenant-Protection Schemes in Southeast and East-Central Europe, 1918-1928*
}

\begin{abstract}
This comparative study analyses a specific socio-political context of the processes that came with the implementation of a housing rent control system in Bulgaria, Yugoslavia, Czechoslovakia and Poland during the first interwar decade. It studies specific interactions between mainstream politics and landlords' and tenants' interest associations. The paper deals with the evolution of the attitudes of tenants' and landlords associations towards the politics and their active participation therein.
\end{abstract}

Key words: housing policy, rent control, interest groups, East-Central Europe, Southeast Europe

This paper deals with complex socio-political implications of the problems resulting from a post-war state intervention in the hous-

This article has been written within a framework of the scholarly project Tradition and Transformation - historical heritage and national identity in Serbia in $20^{\text {th }}$ Century (№ 47019), funded by the Ministry of education, science and technological development of Serbia. Apart from the Ministry, the research was funded by Mediterranean program of the European University Institute in Florence and Imre Kertész Kolleg in Jena. 
ing rental market. ${ }^{1}$ Namely, given that the housing policy could seriously affect the everyday life of a considerable portion of the population, it became an important concern of daily politics. This was especially true as politicians became much more concerned with the welfare of their voters at a time of general liberation and social turmoil after the war. Under the given circumstances, all manifestations of general public resentment or unrest played a significant role in policy decision-making, regardless of their actual political context. Particularly, the well-organized interest associations became associated and involved with political parties and daily politics.

While the landlords' associations stood for the old principles of the inviolability of private proprietorship and the full freedom of contract, the tenants' associations appealed for a prolongation of the state of emergency in the housing domain. Due to their numerical advantage and the new era of mass-politics, the latter were in a more favourable position to influence politics. Even in countries with relatively small urban population (such as Poland, Bulgaria and Yugoslavia), the political influence of tenants' associations went beyond mere numbers. The urban population, especially in capital cities, had significant influence on state institutions. Within context, social unrest of the urban population in close proximity to the seat of political power had a certain weight in a turbulent post-war period.

Chronologically, the paper covers the first inter-war decade, including both the period with the fastest rate of change in post-war development and state intervention in housing rental market, namely the period from 1918 to 1924, and the time of relative stabilization that ended with the global upheaval caused by the Great Depression. The period 1918-1924 proved to be of exceptional importance for this article given that the dynamics of societal and political interactions between the interest groups and politics were at their peak in that period. This is the

1 On the housing rent control system and tenant protection schemes in the four countries under study, see: Александар Р. Милетић, „Нормативно регулисање стамбеног закупа у Европи, 1914-1938“, Токови историје 3/2013, 109141; Александар Р. Милетић, „Сукоб станодаваца и подстанара, 1918-1928. Организација интересних група у југоисточној и источној средњој Европи“, Токови историје 2/2016, 65-92; Aleksandar R. Miletić, „Housing Disputes in EastCentral and Southeast Europe 1918-1928. Comparative Perspectives on Yugoslavia, Bulgaria, Poland and Czechoslovakia", Social Transformation and Mass Mobilization in the Balkan \& Eastern Mediterranean Cities (1900-1923), edited by A. Lyberatos and Chr. Hadziiossif, (Irakleion: Crete University Press, 2013), 79-97. 
reason why the study focused on these years in particular; this refers to both the sources and analytical framework used in this paper.

Apart from this introductory section, the study consists of four more sections. The first one deals with the gradual transformation of socio-political setting behind the tenants' movement. The second section is dedicated to seemingly constant landlords' frustrations and disappointments with mainstream politics and politicians in the four countries under study. The third section covers both the landlords' and tenants' attempts to directly participate in the politics. Conclusions and results of the analyses are presented in the fourth section. The study is written on previously unexplored primary sources. This particular topic and a more general issue of housing rent control in the four countries under study have generally been neglected by regional scholarship.

\section{Tenants' affiliations: from the leftist origins}

to the independent interest associations

In the political arenas of the four countries, and especially at the beginning of the period under review, tenants' interests were primarily advocated by social-democratic and communist parties. While the former were staunch supporters of the peaceful reforms, rent control system (RCS) and requisitioning, the latter demanded confiscation and redistribution of housing facilities. ${ }^{2}$ For instance, the Bulgarian housing legislation of May 1920 was preceded by numerous legislation drafts, proposals, and programs that appeared in the leftist parties' newspapers. Not surprisingly, the most radical ideas and policy proposals came from the Communist Party of Bulgaria (CPB). ${ }^{3}$ Georgi Dimitrov, one of its leaders, and later a notable character in the Bulgarian and international communist movement, demanded both the requisitioning and confiscation

2 Requests for peaceful reforms and appeals for maintaining peace and order in the country were among common themes of journal Narod, official organ of Bulgarian socialists, i.e. so-called "broad socialists" in 1919. Seе: К. Г. Бозбелиев, "Срещу Първи май”, Народ, 30. 4. 1919; “Единственийат път”, Народ, 30.4.1919; “Червена софия", Народ, 2.5.1919. The requisitioning of "rich people's semi-occupied houses" was requested in "Naj-blizki zadači”, Hapod, 12. 5. 1919.

3 The more radical, later communist fraction in the Bulgarian labour movement existed under name of the Bulgarian Workers Social Democratic Party (Narrow Socialist) until its $22^{\text {nd }}$ Congress in May 1919 when it was renamed to the Bulgarian Communist Party (Narrow Socialists). 
of available housing facilities in Sofia. ${ }^{4}$ These two measures, with only a slight linguistic difference, can be found again in the official program of the Communist Party for municipal elections in December 1919. Instead of the term "confiscation", the author(s) of the program used "expropriation". ${ }^{5}$ Few days before the elections, Vasil Muletarov, a Communist MP, laid down a detailed elaboration of the CPB stance on the housing issue in the official publication of the party. ${ }^{6}$ One of his main arguments was that any reform in the domain of housing, including even the most radical forms of expropriation, would have been unsatisfactory if it had not been accompanied with a general scheme of nationalization of banks, the construction building sector, etc. The party leaders maintained these basic political concepts throughout the 1920s.

The Bulgarian Social Democratic Party became more closely involved in the official housing policy since its representatives took part in coalition governments from October 1918 to October 1919. The party's Minister, Krăsto Pastuhov, was, in fact, in charge of drafting an initial version of the housing law which came into Parliament in January $1920 .^{7}$ By that time, socialists were no longer in the government, but they voted for the law and defended it during the Parliamentary debate. It happened that the original socialist draft, which prolonged RCS and introduced rigorous requisitioning practices, was later accepted and carried out by the Stamboliski's agrarian regime, well-known for its interventionist economic program.

During the parliamentary debate over this legislation, Stambolijski made a few rather short statements. The most important debate took place between a socialist MP Pastuhov, defending the government's legislation draft, and a communist MP Vasil Muletarov, who demanded even higher level of state intervention. In addition, there was also one voice raised against the very notion of restriction over property ownership. Mihail Takev, a Bulgarian Democratic Party MP, was the only Bulgarian politician who advocated the interests of landlords. In the parliamentary session, he criticized a housing legislation draft on the high points of justice and legality and sacrosanct principles of the constitution. ${ }^{8}$

4 Dimitrov raised this issue on the session of Sofia's Municipal Council. See: “Жилищният въпрос и софийска община", Работнически вестник, 5. 8.1919.

5 Published as front-page of Работнически вестник, 6.12.1919.

6 Васил Мулетаров, “Жилищната нужда”, Работнически вестник, 3. 12.1919.

7 See Pastuhov's speech in: Стенографски дневнищи на XVIII обикновено Народно сьбрание, (София: Държавна печатница, 1920), 752. 
Takev's centre-oriented Democratic Party still stood for the "old" principles of the inviolability of private ownership, and full freedom of contractual relationships. It is, therefore, not surprising that the party did not win the support of more than about 10 percent of electorate in the 1919 and 1920 elections. The speech was delivered only few weeks before a political opponent assassinated Takev himself. When the new housing draft entered the parliament in December 1920, the Democratic Party remained strongly opposed, but its MPs were no longer as inflexible. One of the MPs, namely, Georgi Danailov, criticized it for some particular shortfalls and inefficiencies and not for being anti-constitutional and therefore unacceptable. ${ }^{9}$

One particular feature of the Bulgarian RCS, namely the absence of the tri-partite principle in housing arbitration, ${ }^{10}$ was established as a result of current political constellations during the parliamentary procedure over the 1920 legislation. The stenographic records show that the decision was purely politically motivated. The issue of a tripartite arbitration model was pointed out among other questions raised by a communist MP Muletarov. He actually tried to undermine the complete legislation project which, in his opinion, was deficient both in details and generally. Yet, in the domain of arbitration, he wanted to be constructive, i.e. to improve the draft. He was insisting on the principles of equal representation of both parties in the Housing Commissions (as was the case elsewhere in Europe), and electoral procedure of choosing these representatives. Neither of these principles was included in the law. The members of the commission were only supposed to have a high school education, to be adults, and recognized as moral persons. During the debate, Muletarov exchanged arguments with Prime Minister Stambolijski on this issue:

"Muletarov: (...) in this legislation draft you state: 'In order to be qualified to become a member of the commission you are supposed to be a righteous citizen'.

9 Стенографски дневници наХІХобикновено Народносьбрание, (София: Държавна печатница, 1920), 823-826.

10 Tri-partite principle in settling housing disputes was widely applied throughout Europe in the 1920s. The arbitration was conducted by specially designed commissions consisting of equal number of tenants` and landlords`representatives and a state appointed president who could impose what was considered a "conciliatory” solution. Милетић, „Нормативно регулисање“, 118-119. For a general phenomenon of the tri-partite commissions in France, Germany and Italy, see: Charles S. Maier, Recasting Bourgeois Europe. Stabilization in France, Germany and Italy after World War I, (Princeton: Princeton University Press, 1988). 
P.M. Stamboliski: which means that you should not be a Bolshevik (Laughter) tenant". ${ }^{11}$

Muletarov: Exactly! He is not supposed to be a communist, i.e. a

In the previous elections of August 1919, communists won more support than the socialists, and their popularity among the urban poor was growing. Perhaps, this is what restrained lawmakers from giving tenants institutional concessions in the domain of housing arbitration. Housing commissions in Bulgaria were administrative, partisan bodies, infamous for all sorts of power abuses and corruption, especially in domain of requisitioning. In this way, a huge political asset, which could have been used to attract support from the urban poor for an agrarian regime, went astray.

State intervention in housing issues affected only part of the urban population of Yugoslavia and Bulgaria, totalling about 20 percent of the population. Their political influence, however, went beyond mere numbers. The urban population, especially in capital cities could have exercised more power against direct political influence on the authorities. The social unrest of urban population organized in close proximity to the seats of political power had specific weight in the turbulent after-war period. The first Yugoslav housing legislation came after the huge demonstrations were organized by the Serbian Social Democratic Party in Belgrade, in March 1919. Actually, the representatives of the Bolshevik fraction, which soon would be integrated into Communist Party of Yugoslavia (CPY) ${ }^{12}$ delivered speeches. ${ }^{13}$ According to the Belgrade Labour Chamber, there were about 15,000 demonstrators (out of about 100,000 inhabitants) on the spot. ${ }^{14}$ It must have been a significant political demonstration even if the numbers were rather overstated. Throughout 1920, the CPY was a key political advocate for tenants' interest. Its official publication Radničke novine [Labour Journal] was very much concerned with tenants' problems and focused on tenants' issue.

The Party was organizing legal support for the tenants and huge rallies thus making systematic public pressure when the housing law

11 Стенографски дневници на XVIII обикновено Народно сьбрание, (София: Държавна печатница, 1920), 735-736.

12 Between April 1919 and June 1920, the official name of the party was the Socialist Workers Party of Yugoslavia (Communists).

13 "Za ukinuće stambene bijede u Beogradu", Sloboda 14, 8. 3.1919.

14 Извештај Радничке коморе 1914-1920, (Београд: Социјалистичка штампарија Туцовић, 1920), 19. 
entered parliamentary procedure in April $1920 .{ }^{15}$ As a part of this campaign, not less than 20 rallies were held throughout Belgrade on April $4^{\text {th }} \cdot{ }^{16}$ As with the Bulgarian socialists, the Yugoslav socialists' attempts to gain support from tenants and more generally from the labouring poor were compromised by the Party's decision to participate in coalition governments during 1919 and $1920 .{ }^{17}$ On the other hand, they were not even trying hard to obtain tenants' votes. For instance, during the April 1920 developments regarding housing legislation, the party's official journal Sloboda [Freedom] did not publish a single report, information or article regarding this issue. In 1918 and 1919, this journal wrote on tenancy issues in a rather academic way, without the zeal and aggressiveness of the communist propaganda. ${ }^{18}$

Not surprisingly, in the first national parliamentary elections in November 1920, the communists won four times more votes than socialists. In all issues regarding the housing domain, communist propaganda came up with more aggressive rhetoric and more radical programs than the socialist. While the socialists insisted on tripartite housing commissions and requisitioning, communist demanded one-party tenants commissions and general confiscations of housing property. ${ }^{19}$ The communists proclaimed a two-level political program: one realistic, which aimed at the prolongation of the protection of tenants, and another one, aiming at the overall revolutionary reform of society which would include the abolishment of private property.

The tenants' support was of such importance for the CPY that they were, as a social group of particular significance, invited by the Party's publication Radničke novine to vote for communist lists on the parliamentary elections in November $1920 .^{20}$ As has already been mentioned, the party won considerable support in the elections, and entered

15 „Против скупоће станова! За заштиту сиромашнога Београда! Велики митинг београдскога радништва и кирајџија“, Радничке новине 87, 14. 4. 1920.

16 „Двадесет великих зборова“, Радничке новине 79, 3. 4.1920.

17 A unified social-democratic organization on the state level Social-Democratic Party of Yugoslavia [Socijaldemokratska stranka Jugoslavije] was founded in April 1920. In December 1921 this party merged with another two socialist factions and formed Socialist Party of Yugoslavia [Socijalistička partija jugoslavije]. Toma Milenković, Socijalisticka partija Jugoslavije, 1921-1929, (Beograd: Institutza savremenu istoriju, 1974), 31-74.

18 „Stanbena bijeda“, Sloboda 4, 5. 11. 1918; „Govor druga V. Bukšega i A. Kristana o zakonu o stanarini“, Sloboda 39, 10. 4.1919.

19 „Naši zahtevi po pitanju stanova“, Радничке новине 79, 3. 4.1920.

20 „Кирајџије!“, Радничке новине 282, 26. 11. 1920. 
the Parliament. Previously, the CPY won a majority of votes in municipal elections in the most important Yugoslav towns, including the capital city of Belgrade, Zagreb, Niš, Osijek, Podgorica, and Skopje. These election victories, however, proved to be the peak of the party's popularity and its achievements in the inter-war period. By the end of 1920, after several terrorist actions against the King and state officials committed by the communist followers, the Party's political propaganda and organizational activities were forbidden by the government; the next year, the Party was legally banned. From that time on, the CPY transformed itself into an underground, secret organization, which prevented it from maintaining its role as a tenants' advocate. In reality, after both leftist parties virtually disappeared as viable political organizations, tenants started organizing themselves into their own interest group associations in 1921.

After it became clear that all parliamentary parties were ready to support their claims, the tenants became cautious about maintaining the strict non-party character of their organization. Yet, the communist activists were trying to infiltrate into the tenants associations as it could be seen from the Belgrade tenants' publication, Kirajdžija. According to the source, not less than 15 officials, led by former president Nisim Almozlino, were expelled from the association on the grounds of being pro-communist on its annual assembly in March $1922 .{ }^{21}$ On this occasion, tenants' representatives of the Belgrade quarter of Dorćol issued a firm statement: "Our association does not belong to any political party [...] we are struggling for our rights by legal means [...] politics cannot and must not infiltrate our association."22

In its beginnings, the Warsaw tenants' association was also inclined towards seeking political support from leftist parties. The association's notes and demands for the Warsaw municipal authorities were submitted via the Polish Socialist Party, "the party which advocates the interests of working people." ${ }^{33}$ The first issues of Lokator included phraseology and slogans of socialist provenance. The language used at the general assembly of the Warsaw tenants' association held on May $6^{\text {th }}$ and June $24^{\text {th }}, 1923$ inclined towards a leftist party more than towards an interest group ideology. The assembly issued two resolutions. The first criticized the government's intention to treat state employees differently from other workers. In the housing domain, for instance, only the former

21 „Из организације. Извештај са годишње скупштине“, Кирајција 2, 30. 4. 1922.

22 „Збор на Дорћолу“, Кирајиија 2, 30. 4. 1922.

23 „Magistrat m. st. Warszawy broni prawa własności“, Lokator 6, 16. 7. 1923. 
benefited from requisitioning schemes. The Warsaw tenants association called for unity of all social groups of workers and branches of the labour movement. This was particularly emphasized in the second resolution: "The general assembly states that a proper outcome of the resistance to the landlords' attack against tenants' rights can be attained by a united campaign of the proletariat with no regard to [individual's] ethnic and party affiliation. From this point of view, the assembly considers separate activities of whichever party or association as those who are dispersing tenants' strengths, and who are drawing water to the landlords' mill, and it calls on all parties standing on the ground of the protection of tenants' rights to consolidate immediately their action in the field of the struggle for the roof over one's head with the tenants associations and workers' parties in Poland." 24

By the end of 1923, these elements of leftist ideology gradually disappeared from the official phraseology of the association, which was transforming itself into a non-political interest group. This transformation was certainly encouraged by frequent communication with the highest state officials and party representatives of all parliamentary groups. From March 1924, as its officials became aware of the influence of their lobbying in parliamentary proceedings on housing legislation, the tenants' association assumed a strictly neutral position towards political parties. ${ }^{25}$ Not only that almost all of the political groups supported prolongation of the RCS in Poland, but one of the MPs, a left agrarian and a Warsaw landlord Wacław Łypacewicz, contributed to strengthening tenants' protection. ${ }^{26}$

The March-April 1924 developments proved to be a turning point in the association's history; the Polish tenants finally realized that they constituted "a huge majority of urban voters", and were an important voice in mass-politics. ${ }^{27}$ When compared to Bulgaria and Yugoslavia, this emancipation from the leftist organization tutorship in Poland was even more remarkable as socialist groups in this country retained much bigger support in electorate and in the Sejm. Not counting the represent-

24 "Ogólnie zebranie członków 2-go związku lokatorów i sublokatorów m.st. Warszawy", Lokator 6, 16. 7. 1923.

25 "W przededniu decyzji", Lokator 12, (March 1924).

26 "Niezwykły kamienicznik. Poseł W. Łypacewicz", Lokator 12, (March 1924).

27 "Ochrona lokatorów według nowej ustawy", Lokator 12, (March 1924). 
atives of ethnic minorities, the leftist parties had about one third of the seats in Polish Parliament on the elections in 1919, 1922 and 1926. ${ }^{28}$

Developments within the Czechoslovakian tenants' movement were quite analogous to those of other three countries under review. In the first place, this refers to the common affiliation and interconnectedness with the leftist movement in the formative period. The landlords' propaganda sources show that even in 1922 and 1923 tenants' association in Brno was dominated by people belonging to different factions of the socialist and communist movement. Among them, probably the most prominent figure was a National Socialist MP František Langr who was often presiding over the association meetings. ${ }^{29}$ In 1925, when Czechoslovak tenants' associations launched their joint publication Obrana nájemníků [The Tenants' Protection] such special relationship was no longer visible in associations' everyday operations.

On the occasion of the drafting procedure for the new housing legislation in 1925, the tenants' publication proved to be indecisive in its critic of the political protagonist of the legislation. ${ }^{30}$ This is a clear indication of a strict non-partisan tactic of the Czechoslovak tenants' association. The new legislation was less benevolent towards tenants, yet their official publication was quite cautious in criticising political parties who were members of the so-called Pětka Coallition. This coalition consisted of five parties including two socialist parties who also agreed to the gradual alleviation of the tenant protection system. The journal only noted that "the leftist opposition" in the Parliament stood against the draft of the law. In the first place this referred to the Czechoslovak Communist Party which maintained its legal activity and was represented in the Parliament throughout the interwar period.

In the elections of 1925, communists won about 13 percent of votes and took a second place among the Parliamentary parties. ${ }^{31}$ They represented a significant political force, yet, at the time, they were opposition party with no real influence on decision-makers. Czechoslovak organized tenants were quite aware of this and focused their attention to the members of ruling coalition of five parties: "[In doing so,] the asso-

28 Adam Próchnik, Pierwsze piętnastolecie Polski niepodległej, 1918-1933: zarys dziejów politycznych, (Warsaw: Książka i Wiedza, 1957), 57, 135, 142.

29 “Dopisy. Z Husovic”, Domov 15, 15 April 1922; „Poplach v Brně“, Domov 6, 10. 2. 1923.

30 „Boj nájemníků a podnájemníků o zákon na ochranu nájemníků”, Obrana nájemníků 1, 31. 3. 1925.

31 Mary Stegmaier and Klára Vlachová, „, The Endurance of the Czech Communist Party“, Politics \& Policy (August 2009), 801. 
ciation was motivated by the fact that among the membership we have adherents of all political parties instigate second who could urge them to either join at least at certain level our cooperative action or not to go up against it." ${ }^{\prime 2}$ The very same strategy, and almost in the same words was elaborated on the associations' congress which was held in Prague November $28^{\text {th }}, 1926$. The non-partisan attitude and quest for a common platform of all the tenants was advocated as the best strategy in approaching decision-makers. It was underlined that association members involved "supporters of both leftist and bourgeois parties." ${ }^{33}$

A bit of remaining leftist phraseology one can find in the May Day editorial column of Obrana nájemníků in 1926. The front page was printed in red and much of text was dedicated to the notion of solidarity among those exploited, which included also social category of tenants. ${ }^{34}$ It should be noted that there was nothing revolutionary in celebrating the May Day which was a state designated public holiday in interwar Czechoslovakia. Yet, throughout the period 1925-1928 covered by this research, no ideological traces of socialist or communist origin could be found anywhere in the journal. In this period, the tenants' organization functioned as a strict interest group association.

\section{Landlords' disenchantment with politicians}

According to the Czechoslovakian landlords' sources, a tenant's position in this country was quite a desirable one. Allegedly, both the old conservative parties and the newly emerging workers' parties from the Czechoslovakian political scene courted the tenants. On the other hand, the threatened landlords' attempts to get open support from the political parties proved to be unproductive. In the new era of universal suffrage and mass-politics, it was difficult to find a pragmatic politician who was prepared to go against the interests of majority urban population. Even those parties who still propagated conservative and liberal ideology did not dare to express public support for proprietors' interests. A speech given by Mr. August Brožek, one of the leaders of the Czechoslovakian landlords' associations at the meeting held in March 1922, revealed a bitter feeling of disappointment and helplessness of Czechoslovakian

\footnotetext{
32 „Boj nájemníků a podnájemníků”.

33 „Politický význam konference nájemnických organisací ze dne 28. listopadu 1926”, Obrana nájemníků 1, 1.1.1927.

34 “První máj a nájemníci”, Obrana nájemníků 6, 1. 5.1926.
} 
landlords. The speech published in Domov, the official publication of the association, expressed his frustration with political parties: "Our real enemies are not those numerous tenants, who can turn a decent home into a real hell, who spoil and damage it, [...] Our enemies are not the housing offices, who very often move against landlords in an unbelievable manner, neither are they the courts, tax offices, and communal authorities, but they are our political parties, all of them, with no exception, since they subjected us to a level of persecution unknown in history. They entrusted the offices and tenants with the powers that enabled them to oppress us at any place or time they wanted." 35

The bitter sentiments were addressed primarily to the National-Democratic Party, which was the most conservative among the major Czech parties, and was supposed to represent what was then considered bourgeois interests. Yet, the tenant protection policy was of such a tremendous importance for broad strata of the Czechoslovakian urban population that there was little political capital to be gained from advocating the abolition or at least the moderation of these measures. "We know that you care much more for the interests of your political parties than for national property, that is our homes; therefore you persecute us in order to obtain the votes of tenant-voters", Brožek commented in his resignation.

In support of this claim, Brožek mentioned a not very reliable account on a particular event from the parliamentary debate in 1920. The session was focused on the issue of increasing the state-prescribed limit of housing rents. Allegedly, the Social-Democrats who supported tenants' interests were ready to accept a 50 percent increase (compared to 1914 level) but a National-Democratic Party MP, the well-known Božena Vikova Kuněticka, proposed not more than 20 percent, which was later accepted. Brožek's informant was Vaclav Johanis, a Social-Democratic MP: "Well, if a bourgeois party is pleased then we will agree to the proposal, of course", Johanis allegedly replied to Kuněticka. ${ }^{36}$ In addition, Brožek addressed some serious accusations against Kuněticka's party colleague, the MP František Lukavský. According to Brožek: "Mr MP Lukavský did support and still supports the idea that the law on the confiscation of housing should be prolonged for only one reason - to make a number of owners vote for the ND party." An overall impression from the Czechoslo-

35 "Nářek persekovaných s politickými stranami nepohne, ale hlasovaci listek", Domov 11, 18. 3.1922.

36 Ibid. 
vakian landlords' association was one of utter despair and disappointment with the political parties and political developments in the newly created state. In some of the Domov texts one finds even reminiscences of good old days of the late Habsburg Empire. ${ }^{37}$

The Yugoslav landlords were equally disappointed by daily politics in the newly created state. Yet, their resentment over politics gradually grew. In its beginnings, the landlords' association was focused on the leftist parties and the protagonist of socialist reforms and communist propaganda: "cadets of Lenin, Trotsky, Bronstein, Béla Kun, and other Jewish bloodsuckers." ${ }^{38}$ To some extent, this negative attitude was expected as the communists were mobilizing the urban poor and organizing protest rallies in favour of tenant-protection regulations, while the socialists were governing this policy from the Ministry of Social Policy. Namely, for almost the entire period between December 1918 and May 1920 the socialists were in charge of the ministry. When the ministerial authorities were entrusted to the left-central Democratic Party (DP), in May 1920, the landlords' association also became engaged in a campaign against this party. By the end of 1922, negative sentiments towards DP in particular and leftist ideology in general were prevailing in the landlords' public discourse. ${ }^{39}$ However, the overall disgust at and disappointment with post-war politics came only after the Ministry of Social Policy became controlled by the most influential and conservative Serbian party, the People's Radical Party, in December 1922.

The very first statements of the newly appointed Minister Ninko Perić enraged landlords. Not only could they not expect support from any political party whatsoever, but it was clear that even this traditionalist and conservative party was maintaining policy measures introduced by the socialists in the extreme circumstances immediately after the war. The language of the landlords' official journal became harsh and unpleasant to the politicians. An avalanche of insults was directed at that time towards ministers who were portrayed as "pitiful figures", "ordinary fools", "pathetic clodhoppers", and even as "wet chickens". ${ }^{40}$ They renamed the Ministry of Social Policy into the "Ministry of Confused Policy and So-

37 „Zákon o ochraně nájemníků“, Domov 19, 8. 5. 1922.

38 „Акција нашег удружења. Пред новим решењем питања о закупу зграда“,Дом 4 (мај 1920).

39 „Пред коначним решењем“, Дом, 22. 12. 1921; „Ванредни збор чланова удружења“, Дом 8, 28. 11. 1922.

40 „Сложно на газде“, Дом 14, 21. 1. 1923. 
cial Misery". ${ }^{41}$ Allegedly, this ministry, "staffed by homeless people", was the source of all evil and incompetence in the housing market. Moreover, by maintaining extraordinary measures the "homeless" officials and employees of the ministry were in the first place protecting their own tenants' interests. After the 1923 turning point, the landlords were to stand against tenants' associations, political parties, and state personnel, who all benefited from the housing legislation: "No, no, and no. We do not approve of being cheated or lied to. This [policy] was created by the homeless of the Ministry of Social Policy, aided later by the homeless of the other Ministries and, equally, by the tenants. They all were yearning to lodge at no cost; they all did not consider the general costliness [...] they only find rents expensive." 42

The Bulgarian landlords' lost faith in politics sooner than their counterparts in Belgrade, no matter that at least one political party stood behind their interests. From the very beginning, their official publication wrote with resignation about post-war politics; yet, an aggressive campaign was only directed against Bolsheviks, i.e. against leftist parties. ${ }^{43}$ Among other alleged wrongdoings, these parties were accused of increasing general costs in the market. For instance, the leftist trade-union action intent on raising workers' personal income was directly boosting other prices, since the labour cost inputs were increased. ${ }^{44}$ In a similar way, the workers' cooperatives, supplied with state printed banknotes, were raising prices of goods on the domestic market. ${ }^{45}$ The landlords who were usually labelled as "vultures" and "profiteers" were trying to prove that actually the responsibility for the daily hardship laid primarily on socialist and communist actions.

The Bulgarian landlords' critical statements against other political parties were always general without differentiating between them or between their ideologies. According to the Domopritežatel, politics is one general entity with all sorts of negative connotations. Quite similar to the rhetoric of their Yugoslav counterparts, they emphasized the fact that the restrictions over property ownership came from "homeless party leaders". Under the circumstances, there was no political option for which the landlords could opt: "All our elected representatives, regard-

41 „Министарство за конфузну политику и социјалну несрећу“,Дом 14, 21. 1. 1923.

42 „Сложно на газде“, Дом 14, 21.1.1923.

43 „Жилищният въпрос“, Домопритежател 5, 15. 1. 1919.

44 „Истинските смутители на обществения реду нас“, Домопритежател 9, 15. 2.1919.

45 „Кои са истинските кожодери“, Домопритежател 8, 1. 3. 1919. 
less of their party affiliation, when they assume the power [...] immediately start to create onerous laws directed against owners' interests and in favor of the homeless." ${ }^{46}$ For this reason, one of the priorities of the landlords' associations was to persuade their members to change radically the way they perceived their political affiliations and political ideas. Instead of "old political parties" based on abstract ideas and beliefs, the landlords association called its followers to opt for a new kind of "social estate party" based on particular interests of their social group. Most of all, the association argued against maintaining loyalty to "the old" political ideas and beliefs: "To hell with [your] ideas and beliefs. You are forbidden to breathe air; you are not allowed to make use of your property which is given to another; and still you are seated and you are babbling about some beliefs and ideas! Don't you see that, today, the whole world has begun to spin round its ancient wheel on only one spoke and that everything is transformed and changed and become unrecognizable everything is placed into the service of [particular] interests, and only interests. [...] The old world is already dying out, and it is transforming itself. The old political parties of yesterday are in convulsions and agonizing, they are about to break apart as the old glue formed of some ideas and beliefs, which joined them together, has already been dissolved [...] and these will inevitably disintegrate in particular parts. [...] New parties will be formed, new groups only based on interests, i.e. the parties of [social] estates!" ${ }^{47}$

According to the Bulgarian landlords, the only way out was a direct participation in politics. Since no party was defending their interests, they were to form their own party. ${ }^{48}$ The next section will show how far Bulgarian, Yugoslav, Czechoslovak, and Polish landlords and tenants advanced in implementing the idea of direct participation in politics.

\section{Interest organizations evolving into political parties}

While in Bulgaria the aforementioned idea of taking part in politics occurred to the landlords' movement in 1919, in Czechoslovakia it happened in 1922 and in Yugoslavia in 1924. Yet, this change of heart seems to be nothing more than an act of desperation. Only in Czechoslovakia and Poland did the landlords' associations try their luck in munic-

46 “Всички на работа”, Домопритежател 6, 30.1.1919.

47 “Какво ни предстоји?”, Домопритежател 9, 15. 3. 1919.

48 Ibid.; “Всички на работа”, Домопритежател 6, 30. 1.1919. 
ipal elections. The Polish Association of the Owners of Immovable Property won about 6,000 votes and two seats in Municipal Council of Lodz. In March 1923, the Landlords' Tax Payers Party [Strana Poplatnická m. d.], which was its official name, won only 2 out of 36 seats in municipal parliament in elections held in the South-Bohemian town of Jindřichův Hradec. Regardless of the poor election result, the Czechoslovakian landlords' association was sure that it was moving in the right direction. ${ }^{49} \mathrm{~A}$ year before, Avgust Brožek, the association's high official was once more reminded of an estimated 2,000,000 owners who might have created a powerful political force in future.$^{50}$ Their counterparts in Yugoslavia contemplated about 200,000 votes - equivalent to 40 MPs who might win seats in general elections. ${ }^{51}$ Yet, no further record of political accomplishments of landlords' associations was available in the period under study. Regardless of much rhetoric and many plans for direct participation in political life, and the same applied to the Bulgarian association.

Born out of a huge social turmoil, the tenants' movements in the four countries also had some political aspirations. When it comes to their ideological grounds, there was a certain degree of uniformity in the way these associations went through their stages of development. In the formative period, they were either part of, or closely related to, the leftist movement. Gradually, as demonstrated above, the associations moved towards non-political and strictly interest group organizations. From this neutral position, they managed to obtain support from almost all influential political groups in their countries. When finally some of these associations decided to consider engaging in politics, it was rather a decision based on their impression of their own importance and power amongst the electorate than on anything else. While landlords entered politics out of sheer desperation, the tenants' motives were quite reversed.

In Belgrade, the Tenants' Party took part in the national elections in 1923. Interestingly, it seems that during the campaign it was only confronted by communists. Since the CPY was officially banned in 1921, its leadership established a new party, namely, the Independent Labour Party of Yugoslavia (ILPY) in order to participate in this election. In the domain of housing issues their main worry was how to combat the activities of the tenants' association. For that purpose, the communist party activists

49 "Poučení z obecnich voleb", Domov, 17. 3. 1923.

50 "Nářek persekovaných", Domov 11, 18.3.1922.

51 „Kongres svojine - Svečana sednica“, Dom 16, 27.4.1924. 
distributed propaganda leaflets against the Tenants' Party. ${ }^{52}$ The organizers of the communist underground movement probably still kept in mind recent times when their party was the undisputed political campaigner for tenants' interests. Yet, the election results must have caused a huge frustration for both party leaderships. While the communists won 1,134 votes, the tenants collected no more than 304 votes out of the ballot of about 18,500.53 The Zagreb tenants' association participated in $1927 \mathrm{mu}-$ nicipal elections and won 2 out of 50 seats in the town's municipal parliament. ${ }^{54}$ The communist activists took the opportunity at the Tenants' Party election meetings to regain support among their old electorate, which caused various small incidents. ${ }^{55}$ From 1924 on, the Polish tenants also insisted on the political action of their association. According to their official journal, the focus of the political activities should have been placed on communal elections. ${ }^{56}$ According to the results of the 1927 elections from the Łódź municipality, the results were more than disappointing. The Tenants and Subtenants Party won only 36 out of about 243,000 votes. ${ }^{57}$ The election results of both the tenants' and landlords' organizations proved that they were quite far away from a successful participation in mass-politics.

\section{Conclusion}

Social and political developments in Europe during the WWI and interwar period proved to be in favour of the organized tenants. Due to their numerical advantage and the new era of universal suffrage and mass-politics, they were in a more favourable position to influence politics than it was the case with the landlords. Even in countries with a relatively small proportion of urban population (such as Poland, Bulgaria, and Yugoslavia), the political influence of tenants' organizations went beyond mere numbers. The urban population, especially in capital cities, could exercise significant influence on state institutions. Under the circumstances, social

52 Leaflet „Ne glasajte za kirajdžijsku listu (1923)“ is available in the Collection of the Biblioteka Matice srpske in Novi Sad: Dk II 701.

53 „Јучерашњи избори“, Политика 5353, 19. 3.1923.

54 „Rezultat zagrebačkih gradskih izbora“, Novosti 246, 5. 9.1927.

55 „Izborni pokret za gradske izbore. Skupština stanarinskog bloka“, Novosti 231, 22.8. 1927.

56 “Lokatorzy do rad miejskich!”, Lokator 19, (October 1924).

57 “Wybory do Rady Miejskiej m. Łodzi”, Dziennik Zarzq̨du Łodzi 43, 25. 10. 1927. 
unrest of urban population displayed in close proximity to the seat of political power had specific weight in the turbulent post-war period.

Yet, regardless of all this advantages and such a favourable position to influence politics, the tenants' movement did not originally came into being as an independent interest group association. In its formative period it evolved as one separate branch within broader social and economic program proclaimed by leftist parties. Immediately after the war and at the very beginning of the 1920s, the tenant interests were advocated by social-democratic and communist parties. Whereas the former were staunch supporters of the rent-control system and requisitioning, the latter demanded confiscation and redistribution of housing facilities. In Bulgaria, the state's involvement in housing issues was intensified during the agrarian regime, notable for its resentment of the urban upper classes.

Some significant changes occurred as a result of decline of political influence of the leftist parties in Yugoslavia and Bulgaria. By August 1922 and June 1923, legal activities of their respective communist parties had already been prohibited. Socialist or social-democrats, on the other hand, had even before lost their ground among electorate. As a consequence, tenants' movement in these two countries was rapidly moving towards a complete emancipation from the leftist groups. This was especially the case after it became apparent that their (i.e. tenants') claims would be supported by almost all influential political groups in these two countries.

In Czechoslovakia and Poland socialist and social-democratic groups had much higher levels of popular support than it was the case in Yugoslavia and Bulgaria. Yet, in these countries one finds the very same trend towards emancipation from the ideological burden and political tutorship by leftist parties. The final separation took place in 1923 and 1924 a bit later than it happened in Southeast European countries under review. From that time on, the tenants`organizations in these countries became truly independent interest group associations.

Landlords` associations, on the other hand, were quite independent in their formative period and later on throughout the 1920s. Contrary to the tenants` associations, landlords were trying hard to obtain support from political parties. Almost continuously, they were faced with bitter disappointments even with the most conservative parties which were expected to defend principles of sacrosanct ownership rights and freedom of disposal with one`s property. 
The tenants' organizations in Czechoslovakia, Poland and Yugoslavia only returned to politics as independent political interest groups. Yet, in neither of these countries did election results correspond to the numerical strength of the tenant population. The landlords` organizations also tried their luck in municipal elections in Czechoslovakia and Poland. Taking into account relatively small share of landlords in Czech and Polish society it is remarkable that they were able to gain some support on these elections.

\section{Sources and literature}

Unpublished sources

- Leaflet „Ne glasajte za kirajdžijsku listu“ [Do Not Vote for the Tenants Party]. Collection of the Biblioteka Matice srpske, Novi Sad, Dk II 701.

\section{Published sources}

- Извештај Радничке коморе 1914-1920. Београд: Социјалистичка штампарија Туцовић, 1920.

- Стенографски дневници на XVIII обикновено Народно сьбрание. София: Дьржавна печатница, 1920.

- Стенографски дневнищи на ХІХ обикновено Народно сьбрание. София: Дьржавна печатница, 1920.

Newspapers

- Дом, for a while in 1923 it was issued as Наш дом (Belgrade)

- Домопритежател, since 1922 Собственик (Sofia)

- Domov (Prague)

- Kupajuuja (Belgrade)

- Lokator (Warsaw)

- Наемател (Sofia)

- Hapod (Sofia)

- Obrana nájemníků (Prague)

- Политика (Belgrade)

- Работнически весник (Sofia)

- Радничке новине (Belgrade)

- Sloboda (Zagreb) 


\section{Literature}

- Maier, Charles S. Recasting Bourgeois Europe. Stabilization in France, Germany and Italy after World War I. Princeton: Princeton University Press, 1988.

- Милетић, Александар Р. „Нормативно регулисање стамбеног закупа у Европи, 1914-1938“. Токови историје 3/2013, 109-141.

- Милетић, Александар Р. „Сукоб станодаваца и подстанара, 19181928. Организација интересних група у југоисточној и источној средњој Европи“. Токови историје 2/2016, 65-92.

- Miletić, Aleksandar R. „Housing Disputes in East-Central and Southeast Europe 1918-1928. Comparative Perspectives on Yugoslavia, Bulgaria, Poland and Czechoslovakia“. Social Transformation and Mass Mobilization in the Balkan \& Eastern Mediterranean Cities (1900-1923), edited by A. Lyberatos and Chr. Hadziiossif, 79-97. Irakleion: Crete University Press, 2013.

- Milenković, Toma. Socijalistička partija Jugoslavije, 1921-1929. Beograd: Institut za savremenu istoriju, 1974.

- Stegmaier, Mary and Klára Vlachová. „The Endurance of the Czech Communist Party“. Politics \& Policy (August 2009), 801.

- Próchnik, Adam. Pierwsze piętnastolecie Polski niepodległej, 1918-1933: zarys dziejów politycznych. Warsaw: Książka i Wiedza, 1957. 


\title{
Резиме
}

Александар Р. Милетић

\section{Стамбени спорови и политика. Друштвено-политички контекст система заштите станара у југоисточној и источној средњој Европи, 1918-1928.}

\begin{abstract}
Апстракт: Ова компаративна студија анализира друштвено-политички контекст процеса који су пратили увођење и примену система регулисаног стамбеног закупа у Бугарској, Југославији, Чехословачкој и Пољској током прве деценије међуратног периода. Чланак разматра специфичну интеракцију која се одигравала између државне политике и интересних организација станодаваца и станара-закупаца. У том контексту нарочита пажња је посвећена развоју концепција које су ове интересне групе имале према политици, укључујући и њихово активно учешће у њој.
\end{abstract}

Кључне речи: стамбена политика, систем контролисаног закупа, интересне групе, источна средња Европа, југоисточна Европа

У одмеравању снага између супротстављених интересних група станодаваца и станара-закупаца доста тога зависило је од њихове бројчане заступљености у друштву. Динамика друштвених и политичких промена у међуратној Европи, а нарочито увођење општег права гласа и развој феномена тзв. масовне политике, поставили су станаре-закупце, као бројнију интересну групу, у повољнији положај. Ово се односи чак и на земље са релативно малим уделом градског становништва, као што је то случај са Југославијом, Пољском и Бугарском, где је политички утицај градског плебса ишао и преко њихове релативне малобројности. Урбано становништво, а нарочито у главним градовима, могло је у великој мери да врши притисак на државне институције. Јавни протест градске популације исказан 
у близини седишта политичке моћи имао је посебну тежину у превратним временима непосредног послератног периода.

И поред свих ових предности које су им се указивале, интересно окупљени станари нису организовали своја удружења сопственом иницијативом. У почетном периоду, ово организовање се спроводило у оквиру политичких организација леве оријентације. Питање успостављања и одржавања система контролисаног закупа (СКЗ) било је део шире социјалне платформе и програма са којима су наступали социјалисти и комунисти тог времена. Постојале су значајне разлике у погледу програма које су прокламовале ове две политичке групације: док су социјалисти очекивали поступну еволуцију система и били задовољни увођењем СКЗ, комунисти су тражили радикалне промене, које су укључивале примену мера конфискације и редистрибуције стамбеног простора. У Бугарској, државна интервенција у односе стамбеног закупа чије су основе поставили социјалисти била је интензивирана за време режима Александра Стамболијског, вође земљорадника који је био познат по презиру који је показивао према „непроизводној“ градској популацији.

У Југославији и Бугарској драстичне промене се дешавају као последица слабљења утицаја партија левог усмерења. Од августа 1922. у Југославији и од Јунског преврата у Бугарској, у обе земље су биле уведене забране рада комунистичких организација. С друге стране, социјалисти су у ове две земље још раније потпуно изгубили значај у бирачком телу. Под овим околностима, покрет организованих станара се убрзано осамостаљивао од странака левице, и организационо и на нивоу кадрова. Таквом развоју догађаја погодовала је и чињеница да су већ током првих послератних година станари-закупци у Југославији и Бугарској успели да на своју страну придобију представнике готово свих утицајних партија.

У Чехословачкој и Пољској различите странке социјалистичке и социјалдемократске провенијенције успеле су да у значајнијем обиму сачувају утицај у бирачком телу. И у овим земљама ипак долази до истоветног тренда: наиме, до 1923/24. долази до организационог осамостаљивања станара-закупаца. Станодавци су се исцрпљивали у непрестаним покушајима да за своју судбину заинтересују партије од утицаја, нарочито странке које су словиле за конзервативне или традиционалистичке. Епилог је током 20-их година био увек исти. Организовани станодавци, некада угледни сталеж рентијера, доживљавали су континуиране фрустрације одлукама поли- 
тичких власти и скупштинских већина да продуже систем ограничења у домену њиховог располагања својином.

Организовани станари у Југославији, Чехословачкој и Пољској вратили су се средином 20-их година политици и то као представници сопствених политичко-интересних група. Биле су то углавном иницијативе локалног карактера које су се завршавале неуспехом и слабим одзивом бирача на локалним изборима. У Пољској и Чехословачкој на истоветан начин су се у неким локалним срединама опробали и станодавци. Фасцинантно је да њихови резултати нису били тако безначајни како би се могло очекивати с обзиром на слабију бројну заступљеност станодаваца у популацији. 